\title{
Adaptasi Psikososial pada Masa Kehamilan \& Nifas
}

\author{
Achir Yani S. Hamid
}

Kehamilan dan melahirkan merupakan suatu peristiwa psikososial yang sangat mempengaruhi kehidupan wanita dan keluarganya baik secara langsung maupun tidak langsung, yang selanjutnya turut menentukkan kualitas kehidupan keluarga. Respons dan kemampuan adaptasi psikososial wanita dalama masa kehamilan dan nifas ditentukan oleh tingkat pencapain tugas perkembangan keluarga, mekanisme koping yang digunakan, usia kehamilan, dan faktor pendukung lain. Pemahaman perawat tentang konsep terkait dengan proses adaptasi psikososial wanita pada masa kehamilan dan nifas, memungkinkan perawat untuk mampu memberikan asuhan keperawatan yang komprehensif dan unik untuk tiap tahap perkembangan keluarga dengan wanita dalam masa kehamilan dan nifas.

Kata kunci: kesehatan mental, wanita, usia reproduksi.

Pregnancy and childbirth are considered as a psychosocial event in woman and her family life which directly or indirectly determine the family's quality of life. Psychosocial response and ability of woman during her pregnancy and postpartum period are determined by the level of the family developmental tasks achievement, coping mechanism, gestational age, and other supporting factors. The understanding of nurse about the related concepts of psychosocial adaptation of woman during her pregnancy and postpartum period will enable nurses to provide a comprehensive and unique nursing care for each developmental stage of family with pregnant or childbirth woman.

Key words: mental health, woman, reproductive age. 